\title{
La critica del sindicalismo revolucionario argentino al parlamentarismo (1905-1912)
}

\author{
Alejandro Belkin
}

UBA

En este artículo desarrollamos la crítica a la democracia burguesa que elaboraron los sindicalistas revolucionarios. Conjeturamos que los debates suscitados en torno a la Ley Sáenz Peña provocaron un punto de inflexión en sus análisis sobre el parlamentarismo. La reforma electoral, especialmente la sanción del voto obligatorio, incentivó sus reflexiones, nutrieron con nuevos conceptos su arsenal argumentativo. Su sistema de ideas se enriqueció, presentando una explicación más compleja de los modernos mecanismos de dominación en la sociedad capitalista.

Desde sus orígenes, los sindicalistas criticaron a la dirección del Partido Socialista porque desatendía el carácter de clase del Estado. Reprobaron la orientación electoralista de la organización, señalaban que nada positivo se podía obtener de las instituciones que pertenecían a la clase enemiga. Su crítica se circunscribía a contraponer las instituciones estatales -señalando su carácter burgués-a las organizaciones del movimiento obrero, especialmente el sindicato. Las primeras simbolizaban el pasado, la decadencia y la corrupción de la sociedad capitalista, mientras que las organizaciones gremiales encarnaban el germen de la nueva sociedad, la regeneración social y la liberación del proletariado.

En 1911, cuando se puso en marcha el debate sobre la Ley Sáenz Peña, los sindicalistas volvieron sobre sus viejas premisas, recordando la indole burguesa del Estado. Sus críticas tuvieron como destinatarios privilegiados, nuevamente, a los socialistas. Sin embargo, en esa oportunidad, ahondaron en los mecanismos de dominación de la burguesía, aportándole mayor densidad teórica a su discurso. En sus análisis, realizaron una exploración más compleja del funcionamiento del Estado y la democracia burguesa. 


\section{Transformaciones en el sistema de dominación}

El sindicalismo revolucionario surgió en un período de transición entre dos formas de dominación política. En la primera década del siglo $\mathrm{XX}$ el régimen oligárquico comenzó a mostrar fisuras indisimulables. La huelga general de 1902 encendió todas las alarmas de la clase dominante, pues dejó en evidencia que los mecanismos de cohesión social vigentes se habian tornado obsoletos. En consecuencia, algunos sectores de la elite estatal propusieron instrumentos alternativos de dominación, que apuntaron a reconstruir el consenso entre las clases subalternas (Suriano, 1989-1990).

El régimen oligárquico se construyó sobre la base de la exclusión absoluta y manifiesta de las clases populares. La participación estuvo bloqueada para las clases subalternas, quedó limitada exclusivamente a las clases propietarias. En ese esquema de gobierno, los partidos de notables jugaron un rol preponderante. El Estado no sólo aparecía como algo antagónico, sino también externo frente a las clases subalternas. En el orden oligárquico, la dominación política fue ejercida por un Estado que, además de ser, se mostró desembozadamente como el aparato coactivo de una clase, la burguesía, y no del conjunto de las clases sociales. El Estado oligárquico apareció transparentemente como atributo, y aparato de imposición coercitiva, de la clase capitalista (Cavarozzi, 1978).

En los inicios del siglo XX el sistema de dominación oligárquico sufrió las embestidas de una joven clase obrera, que consiguió articular un grado de organización y combate nunca visto hasta ese momento. En esas circunstancias, comenzaron a circular con mayor intensidad ideas reformadoras entre los miembros de la elite dominante, producto de esta creciente conflictividad social, "las políticas sociales emergieron como respuesta a los problemas de cohesión social y de legitimidad planteadas por las relaciones de tipo capitalista introducidas por la nueva realidad económica" (Suriano, 1989-1990, p. 109). Además, la ausencia de mecanismos democráticos de gobierno volcaron a fracciones de la burguesía y la pequeño-burguesía a la oposición armada contra el régimen. En esas condiciones, era necesario buscar reformas en el sistema político para garantizar el orden social. ${ }^{2}$ La reproducción

1. "El Estado y las elites liberales pensaron estos problemas como reflejo de la cuestión social y de los conflictos sociales" (Juan Suriano, citado en Hora y Trímboli, 1997: 55)

2. "Al avanzar la primera década del siglo xx, el sistema de gobierno oligárquico chocaba cada vez más con las necesidades primordiales de la burguesía argentina en su conjunto y de su socio mayor, el imperialismo inglés, que era preservar el orden" (Peña, 1973: 7). 
pacifica del sistema era un requisito indispensable para resguardar las enormes ganancias capitalistas.

Los inmigrantes en general y los trabajadores en particular, crearon desde la segunda mitad del siglo XIX una inmensa red de asociaciones étnicas, culturales, politicas y sindicales. ${ }^{3}$ En muchos casos, estas agrupaciones brindaban servicios sociales que el Estado no quiso, no supo o no pudo ofrecer. Estas asociaciones funcionaban de manera autónoma al aparato estatal, quien no había logrado aún penetrarlas ni regimentarlas (Allub, 1975). Desde comienzos del siglo XX comenzó un lento pero sostenido proceso de expansión de las capacidades de intervención del Estado nacional en las cuestiones de índole social. Esta nueva orientación tendrá diversas manifestaciones. Avanzará en modificaciones en el sistema electoral (1902 y 1912), con el objetivo de integrar a los trabajadores en el sistema politico y desactivar los levantamientos armados de fracciones desplazadas de la clase dominante y sectores medios. Al mismo tiempo, se desplegarán diversas iniciativas para regular las relaciones laborales, intervenir en el funcionamiento de las organizaciones sindicales y arbitrar en los conflictos obreropatronales.

En 1904 Joaquín V. González envió al congreso un proyecto de Ley Nacional del Trabajo, procurando regular, encauzar y controlar la creciente conflictividad laboral. En marzo de ese mismo año, Alfredo Palacios fue elegido diputado por la circunscripción de la Boca. En 1905 se aprueba la ley 4611 que estableció el descanso dominical en el ámbito de la Capital Federal. En 1907 fue promulgada la ley 5.291 relativa al trabajo de mujeres y menores. Ese mismo año se crea el Departamento Nacional del Trabajo, el cual tenía como función "recoger, coordinar y publicar todos los datos relativos al trabajo" para contribuir "a las reformas legislativas y administrativas capaces de mejorar la situación social, intelectual y moral de los trabajadores".

La diversificación de funciones del Estado acompañó la progresiva complejidad de la estructura social y económica del país. ${ }^{4} \mathrm{El}$ objetivo de estas medidas, como ya señalamos, fue reconstruir la legitimidad de un régimen político que se encontraba cada vez más cuestionado. Para

3. "Estos inmigrantes desarrollaron comunidades, escuelas, hospitales, sindicatos, partidos y todos los tipos de asociaciones privadas conectadas con el mejoramiento de sus circunstancias de vida y de orígenes nacionales. El Estado oligárquico no podia penetrar esas organizaciones. Las funciones sociales de estas asociaciones de extranjeros eran facilitar servicios sociales que el país era incapaz de ofrecer y también proporcionar medios de integración en la sociedad Argentina" (Allub, 1975: 679).

4. El Estado desarrolló "una mayor división del trabajo, que crecía a medida que la división del trabajo dentro de la sociedad burguesa creaba nuevos grupos de intereses, y por tanto nuevo material para la administración del Estado" (Marx, 1959: 84). 
conseguirlo, la clase dominante tuvo que contemplar, en cierta medida, determinadas reivindicaciones populares..$^{5}$ De esta manera, el Estado fue adquiriendo gradualmente las características de mediador aparente entre las clases (Engels, 1996), rasgo distintivo de las democracias representativas. La naturaleza abiertamente clasista del aparato estatal fue oscureciéndose detrás de una fachada de neutralidad, apariencia que se fue construyendo para presentar al Estado como árbitro entre las clases, defensor de un supuesto interés general. ${ }^{6}$ Esto permitió conferirle universalidad al dominio de la burguesía. Insistimos, este proceso se encontraba en su etapa germinal en la primera década del siglo XX, momento en que surge el sindicalismo revolucionario. Precisamente, la novedad del fenómeno lo tornó más visible, todavía no se había naturalizado/invisibilizado.

El Estado avanzó sobre la superestructura de la sociedad civil, creando ese moderno sistema de trincheras que menciona Gramsci (1984: 151-152), permitiéndole expandir las bases de sustentación del aparato de dominación burgués. Así explica Portantiero este aspecto del pensamiento gramsciano:

Es en el último cuarto del siglo pasado que Gramsci coloca el momento en que comienza una nueva fase del Estado y de la política [...] el rasgo que la especifica es la mayor complejidad de las funciones estatales, que se despliegan en una multiplicidad de prácticas "como organizaciones estatales o como complejo de asociaciones en la vida civil", hasta construir una serie de trincheras institucionales que median la relación entre las masas y el estado-gobierno. (Portantiero, 1983: 44)

El Estado se propone regular, controlar y vigilar las diversas manifestaciones autónomas de la sociedad civil. "El Estado atrapa en la red, controla, regula, supervisa y organiza a la sociedad civil, desde las expresiones más amplias de su vida hasta sus movimientos más insignificantes, desde sus formas más generales de existencia hasta la vida privada de los individuos" (Anderson, 1981). Las nuevas funciones

5. Este proceso guarda similitudes con el concepto de "revolución pasiva" desarrollado por Gramsci, "proceso de transformaciones «desde lo alto" en el que se recupera una parte de las demandas «de abajo», pero quitándoles toda iniciativa política autónoma" (Portantiero, 1983: 44).

6. "El Estado de clase no se interpone entre las clases para separar a los combatientes, sino para vincularlos mediante una relación asimétrica de dominación y explotación. De todos modos, la asimetría no implica unilateralidad. La relación no es unidireccional, y los procesos de mediación engloban también las peticiones y protestas de las clases gobernadas" (Therborn, 1997). 
que asume el Estado permitieron que fuese "dejando de ser un Estado (exclusivo y particular) de los capitalistas para pasar a ser un Estado capitalista, es decir un Estado garante de las relaciones capitalistas y por ende garante de la existencia y reproducción como clase no solo de la burguesía, sino también de la clase obrera y otras clases no ligadas directamente en la producción a la burguesía" (Cavarozzi, 1978: 1343). En definitiva, se fue construyendo un tipo diferente de hegemonía, más propiamente burguesa, donde la dominación se basa en el consentimiento de las masas que parte de la creencia de ejercitar su autogobierno en el Estado representativo. ${ }^{7}$

Las politicas estatales de integración social fueron acompañadas por un salto cualitativo en las medidas represivas. ${ }^{8}$ De esta manera,

el Estado a la vez que comenzaba a elaborar una politica social, promovia una legislación represiva sumamente dura y especializada, perfeccionaba un cuerpo represivo, más precisamente la policía de la capital, destinado a erradicar los elementos "no asimilables" de la clase obrera. (Suriano, 1989-1990: 110)

\section{Critica a la orientación electoralista del Partido Socialista}

Este giro estratégico en las formas de dominación politica impactaron directamente sobre la militancia del Partido Socialista, ahondando paulatinamente las diferencias de opinión preexistentes, hasta volverlas irreconciliables.

El Partido Socialista ponderó positivamente la nueva orientación que asumió el Estado respecto de la cuestión social. Interpretó los avances en materia de legislación laboral como triunfos propios, producto de su prédica en favor de los trabajadores. En especial, el ala reformista de la organización entendía que sus tesis estaban siendo confirmadas por la realidad. La política centrada en la lucha electoral y parlamentaria

7. "Así pues, el Estado burgués «representa» por definición a la totalidad de la población, abstraída de su distribución en clases sociales, como ciudadanos individuales e iguales. En otras palabras, presenta a hombres y mujeres sus posiciones desiguales en la sociedad civil como si fuesen iguales en el Estado. El parlamento, elegido cada cuatro o cinco años como la expresión soberana de la voluntad popular, refleja ante las masas la unidad ficticia de la nación como si fuera su propio autogobierno" (Anderson, 1981: 22).

8. "A medida que la hegemonía oligárquica se siente amenazada, el fortalecimiento de los dispositivos policíaco-militares tiende a ser mayor. No obstante, las clases explotadas van aumentando sus niveles organizativos y de conciencia, con lo que la lucha de clases se torna más álgida" (Boils Morales, 1978). 
fue leída como fructífera y acertada por la conducción mayoritaria del partido.

Sin embargo, hubo sectores de la organización que hicieron una lectura opuesta de la realidad. El ala izquierda entendió que las leyes laborales y la repentina atención que prestaba el Estado a la cuestión social eran producto de las luchas del movimiento obrero. Desde esta perspectiva, las políticas integracionistas buscaban confundir al proletariado, despertando falsas expectativas en las instituciones estatales. La burguesía, amenazada por el despertar de las fuerzas obreras, ofrecía concesiones para mantener su predominio y fortalecer su aparato de dominación. Hicieron especial hincapié en el carácter de clase de las instituciones estatales. Señalaron que los socialistas no debian olvidar que el Estado, incluida la justicia, el parlamento y la policía, estaba al servicio de la clase capitalista y que no podía ser reformado. En el mismo sentido, subrayaron el carácter irreconciliable de los intereses de clase. $\mathrm{El}$ sindicalismo revolucionario surge en este proceso, como una reacción a las políticas integracionistas del Estado y a la recepción favorable que tuvieron por parte de la conducción partidaria.

Como señalamos más arriba, desde sus orígenes, los sindicalistas revolucionarios criticaron las inclinaciones electoralistas del Partido Socialista. Fundaban su rechazo al parlamentarismo en la definición del Estado como una institución de clase, al servicio de la burguesía. Emilio Troise, intelectual y militante sindicalista, sostenía:

Hay una verdad que ningún socialista puede poner en duda, y es que el Estado es un órgano de clase. Él no representa, ni puede representar más que intereses de clase. Su esencia es la salvaguardia del privilegio de la burguesía. ${ }^{9}$

Esta concepción del Estado se mantiene inalterable en el tiempo. Varios años después, los sindicalistas repetirán opiniones similares, el Estado es el "órgano fiel de los intereses de la clase rica y explotadora [...] es el gendarme que guarda la caja fuerte de los ricos y asesina al pueblo productor". ${ }^{10}$

El parlamento, como parte integrante de la maquinaria estatal, era concebido como territorio enemigo. En ese ámbito, nada positivo podía obtenerse para los trabajadores. Sostener lo contrario, afirmaban, acarreaba serios peligros para la clase obrera, porque despertaba falsas expectativas en las instituciones burguesas. Bartolomé Bosio, censu-

9. Troise, Emilio. "La acción directa: refutación a sus detractores", La Acción Socialista, año I, N 1, 11 de julio de 1905, p. 2.

10. “GGuerra al voto!”, La Acción Obrera, año VII, N²26, 6 de abril de 1912, p. 1. 
rando implícitamente la conducta del Alfredo Palacios en el Congreso, señalaba:

Pronto, muy pronto, se echa en el olvido que el Parlamento es de creación burguesa, y que el papel que cuadra a un representante de una clase revolucionaria no es ciertamente el de querer hacer funcionar a esa institución en beneficio de los oprimidos.

El Parlamento es incapaz de satisfacer las necesidades de la clase obrera. Pretender lo contrario es ilusionarse, crear ilusiones peligrosas en la masa obrera, haciéndole vivir en la esperanza de que su mejoramiento y su emancipación es posible por obra y gracia de un pequeño esfuerzo realizado al poner la boleta electoral en la urna, esfuerzo que dará como resultado un cambio de personajes en el Parlamento, los cuales siendo socialistas legislarán para el pueblo obrero, refomarán y, por fin, serán capaces de... crear un sistema socialista!

Estas ilusiones peligrosas, esas esperanzas vanas son el resultado forzoso de la actitud y de las afirmaciones en contradicción con nuestros principios revolucionarios. ${ }^{11}$

El parlamento era considerado como una institución especialmente dañina para la conciencia del movimiento obrero. El congreso aparece como la representación de todo el "pueblo", pero en realidad es un instrumento al servicio de la clase dominante. Su carácter mendaz corroe el sano juicio de la clase obrera. Por esa razón, criticaban a la conducción del Partido Socialista, por las esperanzas que depositaba en las elecciones y en el parlamentarismo. Esa política fomentaba equívocas ilusiones entre el pueblo trabajador. Por estos motivos, su crítica estaba dirigida especialmente al parlamento, al que consideraban "el órgano burgués por excelencia". ${ }^{12}$ Alertaban a los trabajadores sobre las expectativas infundadas que podian despertar el parlamento y la política electoralista del Partido Socialista. "El pueblo obrero no puede esperar el mejoramiento de sus condiciones de vida y de trabajo del funcionamiento de la máquina parlamentaria", ${ }^{13}$ afirmaban. La participación de legisladores socialistas en la cámara de diputados no cambia

11. Bosio, Bartolomé, "La lucha de clases en el parlamento", La Acción Socialista, año I, No 5,11 de septiembre de 1905, p. 2.

12. "Parlamento y sindicato", La Acción Socialista, año I, No 7 , octubre de 1905, p. 2

13. Bosio, Bartolomé, "La lucha de clases en el parlamento", La Acción Socialista, año I, No 5,11 de septiembre de 1905, p. 2. 
el carácter de clase del Estado, porque es "un órgano inadaptable a la finalidad socialista". ${ }^{14}$

Entonces, en momentos en que el Estado comienza a diseñar una política de integración social, los sindicalistas le recuerdan a la conducción del Partido Socialista que el Estado es una institución de clase, que tiene como finalidad defender los intereses de la burguesía. Por lo tanto, nada positivo podía obtenerse del parlamento, ni de la participación electoral.

\section{La inflexión en la critica al parlamentarismo}

Años más tarde, en vísperas de la asunción de Roque Sáenz Peña, insisten con los mismos argumentos. Sostenían que el presidente es "el primer resorte de la máquina de opresión" capitalista. Advertían, en este caso, contra las promesas que realizaba el nuevo mandatario. A pesar de su discurso conciliador, "no dejará de ser el agente de la voluntad de los capitalistas". Veían con preocupación que el flamante gobierno pudiera conseguir los objetivos que se proponía, "si su política se lleva a cabo la colaboración de clase quedará establecida", ${ }^{15}$ afirmaban. Por eso, alertaban a los trabajadores contra las ilusiones que pudiese despertar el recambio presidencial: "el proletariado no puede abrigar -si no quiere tener nuevas desilusiones- ninguna esperanza en [...] los nuevos mandatarios". ${ }^{16}$ Alertaban que "la burguesía quiere despertar la confianza en los trabajadores hacia sus instituciones". ${ }^{17}$ Entendieron que el nuevo gobierno representaba un renovado desafio para la clase obrera y sus propias posiciones políticas. Por ese motivo, redoblaron su prédica antiestatal. Descartaron de plano que el Estado pudiera proteger los intereses obreros: "vanas son las ilusiones de quienes esperan que el poder político de la burguesía sirva como institución de amparo y de defensa proletaria". ${ }^{18}$ Recordaron que el Estado y todas sus insti-

14. Troise, Emilio. "La acción directa: refutación a sus detractores", La Acción Socialista, año I, N 1, 11 de julio de 1905, p. 2.

15. "El nuevo gobierno", La Acción Socialista, año V, N 130,8 de octubre de 1910, p. 1 .

16. "Lo que se impone", La Acción Socialista, año V, N 130, 8 de octubre de 1910, p. 2.

17. "El movimiento obrero y las instituciones burguesas", La Acción Obrera, año VI, $\mathrm{N}^{\circ} 168,14$ de enero de 1911 , p. 3.

18. "El proletariado y el Estado", La Acción Obrera, año VI, N 151, 15 de noviembre de 1910 , p. 1. 
tuciones "han sido creadas por la clase patronal para ampararla en su privilegio de clase". ${ }^{19}$

El discurso gubernamental, teñido de frases altisonantes en favor de la democracia y la libertad, no cambió la opinión de los sindicalistas. Resultaba evidente, para ellos, que el Estado mantenía su naturaleza de clase y su vocación antiproletaria. Porque el discurso democrático del gobierno convivía con la persecución de los militantes proletarios. El nuevo mandatario mantuvo en vigencia la Ley de Residencia (1902) y la Ley de Defensa Social (1910), instrumentos legales para reprimir al movimiento obrero. Cuando en el Congreso se estaba tratando la reforma electoral, fuera del recinto se sucedian las detenciones, deportaciones, arrestos y allanamientos de locales obreros. Los sindicalistas no dejaron de señalar esta contradicción entre el discurso y la realidad, entre las promesas de mayor democracia y libertad, por una parte, y la fuerte represión hacia los activistas obreros, en los hechos. ${ }^{20}$

El saneamiento electoral, prometido por el gobierno, estimuló la reflexión de los sindicalistas sobre el sistema de dominación. Sus argumentaciones tuvieron como eje la dicotomía entre apariencia y realidad. En ese sentido, cuestionaron la categoría de "ciudadano" porque encubría las desigualdades sociales inherentes al sistema capitalista. En un artículo firmado por un tal "Julio", posiblemente Árraga, ${ }^{21}$ se sostenía:

Observamos sorprendidos que en la democracia desaparece el hombre concreto, el hombre real de la vida económica, para ser reemplazado por el tipo abstracto, el "ciudadano", y como este título se extiende a las personas de cualquiera categoría social y económica que fuera, resulta que el "obrero" es un ciudadano como lo es también su patrón el capitalista. ${ }^{22}$

19. "Acción corporativa y acción gremial", La Acción Obrera, año VI, N 178, 6 de mayo de 1911 , p. 1.

20. La FORA también denunciaba la "infame tiranía que padecemos", advertía que "por todas partes y en todos los lugares de la república se están cometiendo verdaderos crimenes con los trabajadores". Pintaba un panorama muy sombrío, similar en algunos aspectos a un régimen dictatorial, mencionaban "el asalto a los domicilios de obreros, llevados a cabo con lujo de brutalidad a altas horas de la noche; el feroz apaleamiento de algunos camaradas del interior de la república; el terror entre las familias de los obreros sindicados como conscientes y revolucionarios". Acusaban a la policía de "vejarnos, prendernos y torturarnos", en "Al proletariado", Organización Obrera: órgano de la Federación Obrera Regional Argentina, 1 de julio de 1912.

21. Destacado militante y teórico del sindicalismo revolucionario argentino.

22. "Democracia Sindicalismo", La Acción Obrera, año VI, No 178, 6 de mayo de 1911 , p. 2. 
El "hombre real" de la vida económica aquí es contrapuesto a la categoría abstracta de "ciudadano" de la democracia. En la realidad existen obreros y capitalistas, la noción de ciudadano enmascara la verdad. También oponen los conceptos de ciudadano y productor, aseguran que

por encima de esa condición [la de ciudadano] está la de productores, más real y tangible [...]. Como trabajadores [...] es preciso que nos consideremos, ante todo, como productores, no como ciudadanos. ${ }^{23}$

La condición de productor era presentada como "más real y tangible" que la de ciudadano. En el mismo sentido, los sindicalistas son reacios a utilizar el concepto de "pueblo", porque hace referencia a una "multitud indefinida formada con elementos de todas las clases sociales", en su lugar prefieren utilizar el término "pueblo obrero". ${ }^{24}$

Este contraste entre apariencia y realidad es utilizado como recurso heurístico para explicar la expansión de las formas democráticas de gobierno. La experiencia acumulada por los capitalistas los condujo a revisar los mecanismos de dominación. Los sindicalistas sostenían que la burguesía llegó

al convencimiento de que una oligarquía no podía sostenerse sino ocultándose y disimulándose detrás de instituciones de carácter democrático y popular. Entonces idearon el siguiente habilísimo plan: reservarse el poder económico, la "realidad" del poder, y entregar al pueblo el poder político, es decir el poder aparente. Desde este momento el pueblo creyó estar en posesión de la dirección de sus intereses.

No sin ninguna vacilación entregaron los capitalistas al pueblo el sufragio universal, pues temian que constituyeran un gobierno que les despojara de sus capitales y de sus privilegios.

Una larga experiencia del sufragio popular y del funcionamiento de la democracia les ha demostrado que ellos no son menos dueños del gobierno aunque personalmente no formen parte de él. Así se ha podido comprobar que el gobierno está siempre a disposición de las reclamaciones de los capitalistas, y entre nosotros vemos con frecuencia que toda concesión o

23. "El voto obligatorio", La Acción Obrera, año VI, N 194, 26 de agosto de 1911, p. 1 .

24. "El voto obligatorio", La Acción Obrera, año VI, N 180, 20 de mayo de 1911, p. 1 . 
pedido hecho por las empresas ferroviarias, bancos, la Liga Agraria, los capitalistas azucareros de Tucumán y otras empresas, son siempre atendidos favorablemente. ${ }^{25}$

Hasta ese momento, su crítica al parlamentarismo se había limitado a denunciar el carácter de clase del Estado, como instrumento de dominación de la burguesía. Ahora, incorporan esta distinción entre poder real y poder aparente. El sistema democrático era un artilugio pergeñado por la clase capitalista para encubrir su dominación de clase, haciéndole creer al pueblo que el gobierno estaba en sus manos. La clase dominante otorgó el sufragio universal, sin embargo mantuvo el control del gobierno, el poder real. Por esa razón, afirman: "la democracia se ha convertido en un biombo, detrás del cual los capitalistas ocultan y protegen su poder". ${ }^{26}$

Los socialistas eran funcionales a este engranaje de dominación. Cuando el proletariado desarrolla altos niveles de movilización, la burguesía necesita encontrar formas para distender las tensiones sociales. Por ese motivo, tienta a los socialistas ofreciéndoles cargos en los poderes públicos y bancas en el parlamento. Desvian la atención del proletariado hacia el callejón sin salida de las elecciones, apartándolo de la acción directa. El gobierno tienta "a los socialistas para que participen del gobierno, a fin de pacificar al proletariado, desorientándolo de su verdadero camino [...] en 'esta época de agitación obrera', con el evidente propósito de despertar en el proletariado su confianza por el Estado". No era un fenómeno exclusivamente nacional, en todas partes del mundo "los gobiernos han llegado a considerar como una "válvula de escape' a las pasiones proletarias [...] la entrada de los socialistas, ora en el parlamento, ora en los ministerios". ${ }^{27}$ De esta forma, la obra conservadora de la burguesía era completada por la participación de los socialistas en las elecciones. Respecto a las esperanzas de los socialistas de conquistar el poder utilizando los engranajes del Estado, afirmaban: "la dotación de personal no cambia las funciones de la máquina". ${ }^{28}$

El sistema democrático burgués tenía la capacidad, también, de fagocitar a militantes que en otro tiempo asumieron posiciones revolucionarias. El caso emblemático era el de Aristide Briand, socialista

25. "Poder real. Poder aparente", La Acción Obrera, año VII, N 215, 20 de enero de 1912, p. 1.

26. Ibídem.

27. "Repitiéndose lo mismo!...", La Acción Obrera, año VII, Nº 218, 10 de febrero de 1912 , p. 1.

28. "Derechos sobrepasados", La Acción Obrera, año VII, No 223, 16 de marzo de 1912, p. 1. 
francés que a comienzos del siglo XX impulsaba la huelga general revolucionaria y años más tarde terminó integrando el gobierno de su país y reprimiendo las protestas obreras. Analizando el panorama político europeo, entendian que estaban en presencia de una estrategia de la burguesía, que consistía en reemplazar los gobiernos abiertamente reaccionarios por otros más progresistas, pero que terminaban siendo peores que los anteriores. Al respecto, afirmaban:

Dentro de los nuevos sistemas republicanos y democráticos han llegado al poder los hombres más exaltados, gentes que predicaban la huelga general y la violencia como medios de lucha proletaria, han llegado a las jefaturas de gobiernos de los principales países europeos; gentes que aconsejaban volar las fábricas para intimidar a los patrones están hoy a la cabeza de las nuevas repúblicas: Briand en Francia y d'Almeida en Portugal. Caen los gobiernos clericales y suben los avanzados, y éstos en el gobierno son peores que los reaccionarios. En España, ni Cánova, ni Maura, llegaron hasta atropellar los derechos de asociación como el actual presidente de ministros, quien, antes, enseñaba el marxismo en las academias y ahora persigue furiosamente a los obreros organizados, disolviendo sus instituciones federales. Recuérdese que este bandolero legalizado subió al poder por la presión que en pocos meses, en pocos días casi derribó a Maura, y sostenido por todos los elementos avanzados de la política y del pueblo.

Hablamos el lenguaje de la experiencia. De ella deducimos una conclusión lógica: todos los gobiernos son iguales; más aún: los gobiernos, cuanto más avanzados, son peores, y cada vez peores para el proletariado y serviles, cada vez más serviles para los capitalistas. ${ }^{29}$

Este nuevo contexto político europeo los lleva a profundizar en sus reflexiones, tratan de explicar los motivos de las mutaciones operadas en estos dirigentes. Ensayan una explicación de tipo materialista: "todos saben que en las alturas todos los hombres se corrompen, [...] ello es debido a la propia organización del Estado y a la estructura de la sociedad capitalista". ${ }^{30}$ Encuentran las razones en los efectos nocivos de la maquinaria estatal. Por eso sostienen: "sube uno revolucionario

29. "Experiencia política”, La Acción Obrera, año VII, N² 225, 30 de marzo de 1912, p. 1.

30. "Hombres políticos", El Obrero en Madera, año IV, No 44, 1 de mayo de 1911, p. 1 . 
al parlamento y baja conservador". ${ }^{31}$ En consecuencia, el efecto es el contrario al buscado por los socialistas, en lugar de ser ellos quienes modificaban la naturaleza del Estado, es el Estado quien provocaba una transformación reaccionaria en los militantes socialistas.

Los sindicalistas introducen un elemento adicional en este -cada vez más- complejo mecanismo de dominación. La prensa es otro de los instrumentos en manos de la burguesía, a través de su control puede moldear a la opinión pública. Los diarios pueden instalar un candidato y hacerlo triunfar en las elecciones, utilizando el siguiente artificio: "la prensa al unísono publica todos los días, en el artículo de fondo, y en los sueltos... que tal candidato es competente, es laborioso, que cuenta con el apoyo de la mayoría, etc. Y así se forma ésta alrededor del candidato y lo hace triunfar". ${ }^{32}$

La prensa y la clase dominante se vinculan por medio de la contribución económica, en materia publicitaria, que realizan los capitalistas a los periódicos. El financiamiento monetario le permite a la burguesía controlar a la prensa. Así describen este dispositivo:

Si alguno de los periódicos como ya ha sucedido, ha iniciado una campaña a favor de un candidato o negocio, que contrarie los intereses y propósitos de la alta banca, pronto tiene un corredor en sus oficinas que le amenaza con retirarles las publicaciones si no cambia su propaganda y entonces el periódico se ve amenazado en su existencia y al día siguiente, ya su propaganda se modifica y pocos días después guarda silencio sobre el asunto. ${ }^{33}$

A través de estos mecanismos, la burguesía consigue controlar a la opinión pública. A su vez, esculpiendo la voluntad de los votantes, logran someter a su arbitrio a las instituciones de la democracia burguesa. Nuevamente, aparece aquí esa dicotomía entre apariencia y realidad, así explicaban la relación entre la prensa, la opinión pública y la clase dominante: "en teoría, la opinión pública gobierna en las democracias, pero en la realidad, son los financistas que por medio de la prensa forman la opinión pública y dirigen las democracias". ${ }^{34}$

Reaparece aquí la dicotomía antes mencionada. En apariencia, "la

31. "Experiencia política", La Acción Obrera, año VII, No 225, 30 de marzo de 1912, p. 1.

32. "Los financistas y la prensa democrática", La Acción Obrera, año VII, No 221, 2 de marzo de 1912, p. 2.

33. Ibídem.

34. Ibidem. 
opinión pública gobierna", pero en realidad gobiernan los financistas. La crítica de la democracia burguesa se vuelve más elaborada, no se circunscribe a señalar el carácter burgués del Estado.

El aspecto que causaba mayor irritación de la Ley Sáenz Peña, entre los sindicalistas, era la cláusula que establecía la obligatoriedad del sufragio. En respuesta, lanzaron una campaña con el objetivo de convencer a los trabajadores para que no concurran a las urnas: "lisa y llanamente es preciso negarse a votar, malgrado de las penas que tal actitud pueda hacernos sufrir". ${ }^{35}$

La sanción del voto obligatorio confirmaba a los sindicalistas en sus convicciones. Por un lado, corroboraba que los trabajadores se desentendian, cada vez más, de la política electoral, por eso la necesidad de obligarlos por la fuerza a concurrir a los comicios. Pero además, ratificaba que las elecciones eran parte de los engranajes de dominación de la burguesía, por eso el afán del gobierno por despertar el interés del proletariado en el sistema parlamentario.

La abstención era un derecho democrático que resultaba cercenado por la nueva ley electoral. Imponer la obligación de votar era contario a las libertades individuales que el propio gobierno decía defender. "Pues para nosotros -decian los sindicalistas-, la abstención de los ciudadanos al uso de sus "derechos" no es más que el uso fiel de los derechos que la democracia misma concede". ${ }^{36}$

Quienes propiciaron la participación electoral de los trabajadores fueron los socialistas, pregonaron que el voto era un arma de combate contra la burguesía. La participación electoral era el camino que debía seguir el proletariado para conquistar su emancipación. Los sindicalistas subrayaron la contradicción entre la prédica socialista y la Ley Sáenz Peña. Si el sufragio universal era un arma de lucha del proletariado, ¿por qué los enemigos de clase obligaban a los trabajadores a utilizarla? Sebastián Marotta, afirmaba:

Es decir, la terrible arma que los pontífices de la democracia social han venido propagando al proletariado para [...] realizar hasta su emancipación, es impuesta obligatoriamente, por la primera cabeza del Estado, representante como se sabe, de la clase dominante. [...] sus propios tiranos se encargarán por libertarlo, obligándole que haga uso del sufragio universal. ${ }^{37}$

35. "El voto obligatorio", La Acción Obrera, año VI, N 194, 26 de agosto de 1911, p. 1.

36. "El voto obligatorio", La Acción Obrera, año VII, No 205, 11 de noviembre de 1911 , p. 1.

37. Sebastián Marotta, "Los trabajadores y el voto obligatorio", La Acción Obrera, año VII, $N^{\circ} 225,30$ de marzo de 1912, p. 2. 
La sanción del voto obligatorio era la demostración, para los sindicalistas, de que el voto no era un arma para la liberación de los trabajadores. La burguesía recurría al sufragio universal y obligatorio para incentivar la anuencia del proletariado hacia las instituciones estatales, para "gobernarlo con su consentimiento, que desde hace mucho tiempo lo está negando [...] otorgando delegaciones a sus enemigos naturales, para que desde las instituciones legislativas sigan, con el consentimiento de todos, oprimiendo al proletariado con leyes zaristas, que prohíben o castigan el ejercicio de la huelga". ${ }^{38}$ Es decir, el voto obligatorio ayuda a relegitimar el sistema de dominación burgués, los trabajadores no conquistarían su liberación depositando una papeleta en la urna.

Los trabajadores -sostenian los sindicalistas- siempre fueron reacios a participar en las elecciones, "el "pueblo" en su inmensa mayoría siempre se ha abstenido de formar comparsa en la farsa democrática de las elecciones". ${ }^{39}$ La baja participación del proletariado, en lo que llamaban la "farsa electoral", la entendian como un acto consciente de la clase obrera. Aseguraban que el proletariado "se desentiende de la democracia". ${ }^{40}$ En el mismo sentido, afirmaban: "los partidos y los comicios se despueblan más cada día, no por ignorancia o por desidia cívica [...] sino por convicción". ${ }^{41}$

Cuando comenzó a discutirse la reforma electoral, propiciada por Roque Sáenz Peña, los sindicalistas estaban convencidos de que los trabajadores iban a mantener inalterable su indiferencia hacia el sistema electoral. "Democracia", "voto libre" y "sufragio universal" eran "cosas huecas" para el pueblo obrero, no significaban "nada real ni concreto". ${ }^{42}$ Los trabajadores no iban a dejarse seducir por ese palabrerío abstracto. Por lo tanto, desde su óptica, la política de saneamiento institucional, alentada por el nuevo gobierno, no iba a tener eco entre los trabajadores.

Sin embargo, a medida que se acercaban las elecciones, fueron cambiando de opinión. En febrero de 1912 advertían que "el gobierno despistó al pueblo y lo predispuso favorablemente para las próximas

38. "El soberano esclavo", La Acción Obrera, año VII, Nº 218, 10 de febrero de 1912, p. 1.

39. "E1 voto obligatorio", La Acción Obrera, año VII, $N^{\circ} 205,11$ de noviembre de 1911 , p. 1.

40. Ibídem.

41. "El manifiesto ante la clase trabajadora", La Acción Obrera, año VII, N²22, 9 de marzo de 1912, p. 1.

42. "El voto obligatorio", La Acción Obrera, año VI, N 180, 20 de mayo de 1911, p. 1. 
elecciones". ${ }^{43}$ Sostenian que los trabajadores interesados en participar de las elecciones fueron sugestionados "o por las lecciones de instrucción cívica recibidas en la escuela, o por la misma instrucción, dada en forma de propaganda obrera emancipadora, recibida en los centros socialistas". ${ }^{44}$ Introducen en el análisis a la escuela, como otra de las instituciones que contribuyen al sistema de dominación burgués. En su afán por explicar el inesperado comportamiento de amplios sectores de la clase obrera, continúan desarrollando su arsenal argumentativo. $\mathrm{El}$ entusiasmo despertado por las elecciones se trasluce en la siguiente crónica:

Los obreros, convertidos en ciudadanos, abandonando su personalidad concreta y real de productor, transformados en personajes alegóricos, han paseado entusiastas por las asambleas politicas donde los candidatos les predicaban que si deseaban mejorar sus condiciones y aproximarse a su emancipación, les bastaba depositar su voto en la urna electoral, con el objeto de elegir al diputado socialista que desde las bancas del parlamento realizaria aquellas bellas aspiraciones.

No necesitaba hacer huelgas parciales, generales, luchas contra el estado, la policía, propagar sus propósitos de rebeldía en los talleres y centros obreros, gastando dinero y llamando sobre su persona los odios y hostilidades de los patrones y de la autoridad. El voto que le reclaman los políticos no es tan penoso, ni compromete su libertad y su vida. ¿Qué propósitos llevan al parlamento los diputados socialistas? Hacer que el estado, que en la actualidad sirve a los capitalistas, en adelante sirva a los obreros. ${ }^{45}$

Los sindicalistas revolucionarios lamentaron que muchos trabajadores hayan participado del proceso electoral. La creencia en el parlamentarismo fue "inculcada astutamente en la conciencia de los trabajadores, ha hecho que ellos se confien en sus diputados en vez de esperarlo todo de sus sindicatos". ${ }^{46} \mathrm{El}$ proletariado tendrá que experimentar en carne propia que la democracia burguesa no soluciona ninguno de sus proble-

43. "El gobierno y las elecciones", La Acción Obrera, año VII, No 220, 24 de febrero de 1912 , p. 2.

44. "Derechos sobrepasados", La Acción Obrera, año VII, N 223, 16 de marzo de 1912 , p. 1.

45. "La conquista al poder", La Acción Obrera, año VII, Nº 229, 1 de mayo de 1912, p. 2.

46. "El Parlamento y el Sindicatos", La Acción Obrera, año VII, N 223, 16 de marzo de 1912 , p. 2. 
mas, "desgraciadamente hay que esperar todavia que los hechos futuros les abran los ojos a los extraviados obreros que buscan en los partidos y en los gobiernos más libertad y más bienestar". ${ }^{47}$ Los sindicalistas sostenían que los hechos enseñan. La experiencia es la única vía por la cual el proletariado puede desarrollar su conciencia, descorrer el velo construido por la burguesía para ocultar la realidad. Por ese motivo, las elecciones de 1912 tenian un aspecto positivo, porque permitirian a la clase obrera ejercitar los mecanismos electorales y comprender que "la democracia y los partidos son impotentes para sacarlos de las condiciones opresivas y miserables a que los ha reducido la burguesía". ${ }^{48}$ Sus afirmaciones, entendian los sindicalistas, eran juicios derivados de lo acontecido en otros países:

En todos los países donde el sufragio no existe, los males sociales, desde la miseria y la desocupación a la opresión y los abusos, son atribuidos a la falta de esta ilusión deslumbrante, que es reclamada con imperiosidad invencible. Pero donde, por circunstancias históricas determinadas, el sufragio está establecido, su eficacia como remedio de males económicos, puesta al juicio de la experiencia, queda evidenciada como de valor nulo. ${ }^{49}$

El triunfo del radicalismo también fue pensado con los mismos criterios. La incorporación de los opositores en el sistema político permitiría que, experiencia mediante, se desvanezcan las esperanzas depositadas en la UCR. Los trabajadores podrian comprobar en la práctica la ineficacia de la propuesta radical:

El triunfo de la oposición radical será benéfico porque importará una experiencia y la caída de muchas ilusiones en el seno de la masa [...] cuando se vea, en fin, que la lucha no es dirigida a suprimir malas prácticas administrativas, sino a cambiar de manos las cosas..$^{50}$

Sin embargo, todavía quedaba un largo camino por recorrer, pero era imprescindible comenzar a transitarlo:

47. "Los políticos fortifican el Estado, nosotros fortificamos los Sindicatos", La Acción Obrera, año VII, No 228, 20 de abril de 1912, p. 2.

48. Ibídem.

49. "Derechos sobrepasados", La Acción Obrera, año VII, N 223, 16 de marzo de 1912 , p. 1.

50. "Política de colaboración", La Acción Obrera, año VII, Nº 227, 13 de abril de 1912, p. 1. 
Muchos años pasarán para quitar los prejuicios políticos del seno de la masa, pero para empezar debía darse comienzo a la entrada de la oposición, pues hasta ahora todas las responsabilidades caían sobre la oligarquía. [...] La entrada de la oposición, lejos de debilitar al gobierno, como parece lógico, lo reforzará con nuevos prestigios. [...] el gobierno, el estado, las instituciones todas de la defensa burguesa, estarán como rejuvenecidas por algún tiempo. ${ }^{51}$

Los cambios políticos operados, a consecuencia de la Ley Sáenz Peña, ayudarian a los trabajadores a tomar conciencia de que las elecciones eran una farsa. No obstante, ese proceso insumiría varios años. En lo inmediato, las instituciones burguesas se fortalecerian.

\section{Excurso teórico}

Los sindicalistas se esforzaron por develar los diferentes mecanismo de control politico construidos por la clase dominante para garantizar su hegemonía. Su crítica excedia la diatriba elemental hacia los organismos estatales de represión. En sus argumentaciones, hacian referencia a un conjunto de instituciones que formaban parte de este complejo engranaje. La educación, el sistema electoral, el parlamento, los medios de comunicación, los partidos políticos y la familia, eran mencionados como instrumentos al servicio de la dominación burguesa. La ideología democrática, con sus nociones de pueblo "en general" y especialmente de ciudadanía, acompañaba esta maquinaria de encubrimiento de la realidad social. El aspecto esencial que se trataba de ocultar era la división de la sociedad en clases con intereses antagónicos e irreconciliables.

Los sindicalistas no fueron los únicos que señalaron la existencia de dispositivos de control social más sofisticados, amén de los instrumentos más evidentes como las fuerzas de seguridad. Entendemos que puede resultar fructifero realizar un contrapunto con ciertas interpretaciones marxistas, puede contribuir a iluminar las peculiaridades de los postulados sindicalistas.

En ese sentido, vamos a introducir algunos conceptos elaborados por Louis Althusser, en su clásica obra Ideología y aparatos ideológicos de Estado (1988), escrita entre los años 1969 y 1970. En la tradición marxista, señala el autor, el Estado es concebido explícitamente como aparato represivo para asegurar la dominación de la burguesía sobre la clase obrera. Presentada de esta forma, asegura, la teoría marxista del Estado abarca lo esencial y expone perfectamente su función funp. 1 . 
damental. Sin embargo, esta definición se ubicaría dentro de lo que denomina la teoría "descriptiva" del Estado. El momento "descriptivo" representa el comienzo de toda teoría. En ese estadio, la teoría nos brinda lo esencial pero representa una etapa en su constitución que exige que sea superada. Si esto no sucede, corre el riesgo de bloquear su desarrollo de la fase "descriptiva" a la etapa superior de teoría "a secas" (tout court). Para desarrollar la teoría marxista del Estado, sostiene el filósofo francés, es indispensable agregar otro aspecto de la realidad. Junto con los Aparatos Represivos del Estado (ARE), contemplados en la teoria "descriptiva", debemos incorporar los Aparatos Ideológicos del Estado (AIE). Estos últimos están formados por instituciones distintas y especializadas, entre las cuales se encuentran: el sistema escolar, las iglesias, la familia, los medios de comunicación masivos, los partidos políticos, los sindicatos y el sistema judicial, entre otros. Los AIE aseguran la reproducción misma de las relaciones de producción, amparadas por el escudo protector de los ARE.

Encontramos algunos paralelismos entre los argumentos esgrimidos por los sindicalistas y las tesis de Althusser. En sus origenes, los sindicalistas revolucionarios se limitaban a señalar el carácter de clase del Estado y su politica represiva hacia el movimiento obrero. En sus primeros tiempos, la teoría sostenida por los sindicalistas sobre el Estado se encontraba -siguiendo el esquema althusseriano- en su fase "descriptiva". Permaneció en esa condición por varios años. Los debates en torno a la Ley Sáenz Peña desbloquearon el desarrollo teórico y permitieron que los sindicalistas superen ese estadio inicial. En ese segundo momento, incorporaron -con mayor precisión- un conjunto de instituciones que contribuian a proteger la reproducción pacífica del sistema. Por supuesto, a diferencia de Althusser, no incluyen a los sindicatos dentro de los dispositivos de dominación. Entonces, los sindicalistas, al igual que Althusser, comprenden que el Estado cumple su cometido (asegurar la dominación de la burguesía) no sólo con el recurso de la fuerza, también utiliza un conjunto de instituciones que cumplen la función de difundir la ideología dominante, como forma de resguardar y sostener al sistema capitalista.

Hemos visto que los sindicalistas desaprobaban la utilización del término ciudadano, porque entendian que era un concepto engañoso, que encubría la división en clases de la sociedad. En la tradición marxista, la noción de ciudadanía también ha sido objeto de críticas. Los análisis sobre este concepto remiten como fuente primaria a El capital de Marx. Al finalizar el capitulo 4 del tomo I, Marx se predispone a abandonar la 
esfera de la circulación para ingresar en el ámbito de la producción. Se propone seguir los pasos de dos personajes alegóricos, el poseedor de dinero y el poseedor de la fuerza de trabajo. El primero ha comprado la mercancía que ofrecía el segundo y se encamina hacia el lugar de trabajo para consumirla. En ese momento, Marx dice:

Abandonamos, por tanto, esa ruidosa esfera instalada en la superficie y accesible a todos los ojos, para dirigirnos, junto al poseedor de dinero y al poseedor de fuerza de trabajo, siguiéndoles los pasos, hacia la oculta sede de la producción. (Marx, 1990: 213)

Subrayemos el contrapunto que presenta Marx, la esfera de la circulación se encuentra "instalada en la superficie y accesible a todos los ojos", por el contrario, la "sede de la producción" se halla "oculta". Marx describe así la esfera de la circulación:

La esfera de la circulación o del intercambio de mercancías, dentro de cuyos límites se efectúa la compra y la venta de la fuerza de trabajo, era, en realidad, un verdadero Edén de los derechos humanos innatos. Lo que allí imperaba era la libertad, la igualdad, la propiedad y Bentham. iLibertad!, porque el comprador y el vendedor de una mercancía, por ejemplo de la fuerza de trabajo, sólo están determinados por su libre voluntad. Celebran su contrato como personas libres, jurídicamente iguales. El contrato es el resultado final en el que sus voluntades confluyen en una expresión jurídica común. jIgualdad!, porque sólo se relacionan entre sí en cuanto poseedores de mercancías, e intercambian equivalente por equivalente. ¡Propiedad!, porque cada uno dispone sólo de lo suyo. ¡Bentham!, porque cada uno de los dos se ocupa sólo de sí mismo. (Marx, 1990: 214)

Para Marx, las relaciones sociales que establecen los seres humanos en la esfera de la circulación son las que generan las ideas de libertad e igualdad que enarbolan los ideólogos del capitalismo. Esta es la base material que origina la falaz apariencia de igualdad entre personas que pertenecen a clases sociales diferentes. La noción de ciudadanía se sustenta en esta representación del mundo, donde todos los ciudadanos aparecen como iguales. "Esta explicación de las ideas modernas de igualdad, deducidas de las condiciones económicas de la sociedad burguesa, fue dada primeramente por Marx en El capital' (Engels, 1975: 88). A diferencia del pensamiento marxiano, para los sindicalistas, los conceptos de ciudadanía, libertad e igualdad, son artilugios creados 
por los capitalistas, no mencionan ninguna articulación con el mundo material. Son ideas artificiales, construidas por la burguesía para confundir al proletariado y mantener su dominación.

Continuemos con el relato que realiza Marx. En la historia que estaba narrando, los personajes se encaminaban hacia la esfera de la producción. Cuando iniciaron su recorrido aparecian como iguales, ambos propietarios de mercancias, que intercambiaban por equivalente en el mercado gracias a su libre voluntad. Sin embargo, a medida que se acercan a la "oculta sede de la producción", Marx nota que los protagonistas del drama se van transformando, así dice:

Al dejar atrás esa esfera de la circulación simple o del intercambio de mercancias, en la cual el librecambista vulgaris abreva las ideas, los conceptos y la medida con que juzga la sociedad del capital y del trabajo asalariado, se transforma en cierta medida, según parece, la fisonomía de nuestras dramatis personæ [personajes]. El otrora poseedor de dinero abre la marcha como capitalista, el poseedor de fuerza de trabajo lo sigue como su obrero, el uno, significativamente, sonrie con ínfulas y avanza impetuoso; el otro lo hace con recelo, reluctante, como el que ha llevado al mercado su propio pellejo y no puede esperar sino una cosa: que se lo curtan. (Marx, 1990, p. 214)

La trasmutación de los personajes nos muestra que la igualdad y la libertad eran solo aparentes. El poseedor de dinero era en realidad un capitalista y el poseedor de fuerza de trabajo era en verdad un obrero. Más aun, Marx señala que el poseedor de la fuerza de trabajo sigue al capitalista como "su obrero". En el mundo de la producción se derrumban las apariencias y salen a la luz los aspectos esenciales de la realidad. La "república del mercado" oculta el "despotismo de la fábrica" (Pashukanis, 1976: 14). En la sociedad capitalista la igualdad es una falacia, por el contrario, se encuentra dividida en clases sociales con intereses antagónicos. En este caso, encontramos algunas similitudes con el pensamiento sindicalista. Estos también afirman, o dejan entrever, que la "sede de la producción" se mantiene oculta. Además, sostienen que es en la esfera de la producción donde la supuesta igualdad se demuestra ilusoria. Para los sindicalistas esta es la realidad que el concepto de ciudadanía viene a ocultar. Sin embargo, a diferencia de Marx, quien afirma que son las relaciones mercantiles las que engendran esas ideas, para los sindicalistas, es en la esfera de la política parlamentaria donde se generan las ideas engañosas de libertad, igualdad y ciudadanía. 
Los sindicalistas distinguían entre poder aparente (político) y poder real (económico). No fueron los únicos que advirtieron sobre esta escisión entre estos dos ámbitos de la vida social. Los marxistas han señalado que la disociación entre la esfera económica y la política es una particularidad del sistema capitalista, "el capitalismo ha abierto una brecha entre lo económico y lo político" (Meiksins Wood, 2000: 26). Principalmente, significa que "los mecanismos de extracción del excedente son económicos; el trabajador, no propietario de los medios de producción, está obligado a vender su fuerza de trabajo al capitalista; la coerción político-militar actúa como garante o marco de la explotación" (Astarita, 2004: 157). Marx afirmaba que:

Solamente en su condición de poseedor de las condiciones de trabajo es como [...] el comprador [el capitalista] hace que el vendedor [de la fuerza de trabajo] caiga bajo su dependencia económica; no existe ninguna relación política, fijada socialmente, de hegemonía y subordinación. (Marx, 1972, p. 61)

En la sociedad burguesa, la apropiación del excedente tiene lugar en la esfera económica con medios económicos. El capitalismo, en este aspecto, difiere de las formaciones sociales precapitalistas. La forma de extracción del excedente en el capitalismo "marca una diferencia con otros modos de producción en los que hay que emplear la fuerza de manera directa para extraer el excedente" (Astarita, 2010). En sintesis:

La diferenciación de la esfera económica en el capitalismo puede resumirse de la siguiente manera: las funciones sociales de producción y distribución, la extracción de excedentes y la apropiación, y la asignación de la fuerza de trabajo social están, por así decirlo, privatizadas, y se logran por medios no autoritarios y no politicos. (Meiksins Wood, 2000: 36)

En la sociedad mercantil, los propietarios capitalistas han conseguido el control directo de la producción, como "en ningún otro sistema la producción social ha respondido tan pronto y de manera universal a las demandas del explotador" (Meiksins Wood, 2000: 38). Sin embargo, los capitalistas individuales carecen de fuerzas represivas propias, "el poder coercitivo que respalda la explotación capitalista no está manejado directamente por el apropiador" (Meiksins Wood, 2000: 37). La potestad de apropiarse del trabajo excedente no está vinculada a las funciones militares, jurídicas y administrativas. Es el Estado moderno el que concentra estos atributos y dispone de cierta independencia relativa respecto a la clase dominante. Por estas razones, los cambios en el personal que ocupa la dirección del Estado no modifican sustan- 
cialmente los derechos de apropiación del trabajo excedente que poseen los propietarios capitalistas.

En definitiva, la distinción que realizaban los sindicalistas, entre poder económico (real) y poder político (aparente), podría encontrar su base de sustentación material en la separación estructural que existe en capitalismo entre la esfera económica y la política.

$$
* * *
$$

La Ley Sáenz Peña representó, en términos de T.H. Marshall, la consolidación del elemento político de la ciudadanía (Marshall, 1997). En otras palabras, se ampliaron los derechos ciudadanos. Sin embargo, para los sindicalistas, estos cambios en el sistema electoral permitieron relegitimar las instituciones del Estado capitalista. La "democracia ampliada", lejos de debilitar el aparato de dominación burgués, apuntaló las instituciones del sistema. Los derechos adquiridos por las clases explotadas terminan transformándose en nuevos mecanismos de integración política al Estado. Este proceso ha sido estudiado también por el marxismo. Renata Gonçalves señala que "incluso la ciudadanía social, resultado de un amplio proceso de luchas, significó, en lugar de más autonomía de los sujetos, mayor legitimación del Estado" (Gonçalves, 2004). Por su parte, Boaventura de Sousa Santos, refiriéndose a la extensión de derechos sociales, afirma:

Políticamente, este proceso significó la integración política de las clases trabajadoras en el Estado capitalista [...] De ahi que las luchas por la ciudadanía social hayan culminado en la mayor legitimación del Estado capitalista. (Santos, 1999: 211)

Renata Gonçalves, sugiere que la ampliación de la ciudadanía representa un obstáculo para la organización independiente del proletariado, y dice así:

En otros términos, es justamente la constitución de la bella esfera de la igualdad, asegurada por la ciudadanía, lo que representa un obstáculo fundamental para la organización del proletariado como clase distinta y antagónica en relación con aquella que detenta el poder político en la sociedad burguesa. (Gonçalves, 2004)

En definitiva, el recorrido que hemos realizado en este apartado, nos invita a sospechar que ciertas ideas que los sindicalistas esbozaron a comienzos del siglo XX anticiparon algunos debates que reaparecerán 
más adelante, tanto en las ciencias sociales como en las discusiones políticas. No fue nuestra intención señalar la genealogía de ciertos conceptos. Sólo hemos querido despertar el interés del lector por ciertas similitudes entre algunas ideas. Esta confrontación de conceptos permite, además, precisar el discurso del sindicalismo revolucionario argentino, echar luz sobre sus contornos, muchas veces difusos. También podriamos conjeturar que, en esa coyuntura histórica, los sindicalistas aventajaban a socialistas y anarquistas en cuanto al desarrollo conceptual de sus análisis sobre los modernos mecanismos de dominación.

\section{Conclusiones}

Los sindicalistas emergieron como una corriente crítica de las políticas integracionistas del Estado y de su consentimiento por parte de la dirección del Partido Socialista. Fundamentaron sus posiciones en el carácter de clase del Estado. En los primeros años de su existencia no avanzaron más allá en sus argumentaciones. El debate que se generó en torno a la Ley Sáenz Peña los obligó a volver sobre sus viejas premisas. Sin embargo, en el desarrollo de la discusión, incorporaron nuevos elementos que no estaban presentes un su discurso original. El análisis de los mecanismos de la dominación burguesa gana en precisión y en espesor argumentativo. La explicación del funcionamiento de la democracia burguesa devino más compleja. El Estado mantiene su naturaleza de clase, pero la forma democrática de gobierno permite ocultar su carácter burgués. La prensa se ubica como un instrumento preciado en manos de la burguesía, pues le permite influir sobre la opinión pública y a través de ésta en las decisiones del sistema democrático.

Mientras los socialistas festejaron acríticamente la democratización del sistema electoral y los anarquistas desestimaron esos mismos cambios, los sindicalistas elaboraron una explicación más compleja del sistema de dominación burgués. La Ley Sáenz Peña representó un desafio enorme para los postulados constitutivos de la corriente sindicalista: su crítica a los dispositivos estatales de integración/dominación. Los sindicalistas respondieron expandiendo su repertorio argumentativo, ampliaron su crítica de la democracia burguesa, entendida como la forma más sofisticada de dominación política del capital. Quizás fueron los únicos que advirtieron que se estaban produciendo cambios profundos en la vida política del país, que impactarian de manera decisiva en todas las fuerzas políticas y en el movimiento obrero.

Las derivas posteriores del sindicalismo revolucionario, sus mutaciones y vínculos con los gobiernos radicales, exceden los objetivos del presente trabajo y tendrán que ser examinados en futuras investigaciones. 


\section{Bibliografia}

Allub, L. (1975), "Estado y sociedad civil en Argentina: patrones de emergencia, desarrollo y estabilidad del Estado argentino", Revista Mexicana de Sociología, vol. 37, $\mathrm{N}^{\circ} 3$, julio-septiembre, pp. 655-696.

Althusser, L. (1988), Ideología y aparatos ideológicos de Estado. Freud y Lacan, Buenos Aires: Nueva Visión.

Anderson, P. (1981), Las antinomias de Gramsci: Estado y revolución en Occidente, Barcelona: Fontamara.

Astarita, R. (2004), Valor, mercado mundial y globalización, Buenos Aires: Ediciones Cooperativas.

Astarita, R. (2010), Respuesta a una critica del profesor Kohan, marzo, en http://rolandoastarita.com/Respuesta\%20NestorKohan.htm [11 de julio de 2013].

Boils Morales, G. (1978), "Progresismo militar en América Latina durante el período entre guerras", Revista Mexicana de Sociología, vol. 40, N 3 , julio-septiembre, pp. 851-866.

Cavarozzi, M. (1978), "Elementos para una caracterización del capitalismo oligárquico", Revista Mexicana de Sociología, vol. 40, N 4, octubrediciembre, pp. 1327-1352.

Engels, F. (1975), Anti Dühring, Buenos Aires: Cartago.

Engels, F. (1996), El origen de la familia, la propiedad privada y el Estado, Madrid: Fundamentos.

Gonçalves, R. (2004), "Ciudadania, clases populares: el lado oculto de la dominación capitalista de clase", Herramienta, vol. 9, $\mathrm{N}^{\circ} 27$, octubre, pp. 107-114.

Gramsci, A. (1984), Cuadernos de la cárcel, tomo 3, México: Era.

Hora, R. y J. Trímboli (1997), "Estado, anarquismo y reforma social. Entrevista de Roy Hora y Javier Trímboli", Todo es Historia, No 354, enero, pp. 52-58.

Marshall, T.H. (1997), "Ciudadanía y clase social”, Revista Española de Investigaciones Sociológicas, No 79, pp. 297-344.

Marx, K. (1959), El dieciocho brumario de Luis Bonaparte, Buenos Aires: Anteo.

- (1972), El capital: Libro I, capitulo VI, inédito, Buenos Aires: Siglo Veintiuno.

- (1990) El capital: crítica de la economía política, Libro primero: el proceso de producción de capital (vol. I), México: Siglo XXI.

Meiksins Wood, E. (2000), Democracia contra capitalismo: la renovación del materialismo histórico, México: Siglo XXI.

Pashukanis, E.B. (1976), La teoría general del derecho y el marxismo, México: Grijalbo.

Peña, M. (1973), Masas, caudillos y elites: la dependencia argentina de Yrigoyen a Perón, Buenos Aires: Fichas.

Portantiero, J.C. (1983), Los usos de Gramsci, Buenos Aires: Folios. 
Santos, B.d.S. (1999), Pela mão de Alice: o social e o politico na pós-modernidade, $7^{\mathrm{a}}$ ed., Porto: Edições Afrontamento.

Suriano, J. (1989-1990), "El Estado Argentino frente a los trabajadores urbanos: política social y represión (1880-1916)", Anuario $N^{\circ} 14$, Escuela de Historia. Facultad de Humanidades y Artes. Universidad Nacional de Rosario, segunda época, pp. 109-136.

Therborn, G. (1997), ¿Cómo domina la clase dominante?: aparatos de estado y poder estatal en el feudalismo, el capitalismo y el socialismo, Buenos Aires: Siglo XXI.

$$
* * *
$$

Resumen: En este artículo nos proponemos desarrollar la crítica a la democracia burguesa que elaboraron los sindicalistas revolucionarios. Se plantea que sus apreciaciones sobre el parlamentarismo tuvieron como punto de inflexión los debates suscitados en torno a la Ley Sáenz Peña. La reforma electoral, especialmente la sanción del voto obligatorio, incentivó sus reflexiones. Su sistema de ideas se enriqueció, presentando una explicación más compleja de los modernos mecanismos de dominación en la sociedad capitalista. Algunos de los tópicos que encontramos en sus argumentaciones fueron retomados posteriormente por las ciencias sociales y en los debate politicos. En comparación con sus rivales en el movimiento obrero, los sindicalistas revolucionarios habrian desarrollado un análisis más sofisticado sobre los cambios que se estaban produciendo en el sistema de dominación.

Palabras clave: Sindicalismo revolucionario - Ley Sáenz Peña - Parlamentarismo - Movimiento obrero

Abstract: In this article we intend to develop the criticism of bourgeois democracy that developed the revolutionary syndicalists. It is stated that his assessments on parliamentarism had as the turning point in the debates around the law Sáenz Peña. The electoral reform, especially the punishment of the compulsory voting, incentive their reflections. His system of ideas was enriched, presented a more complex explanation of the modern mechanisms of domination in the capitalist society. Some of the topics that we find in its arguments were subsequently re-addressed by the social sciences and in the political debate. In comparison with its rivals in the labor movement, the revolutionary syndicalists would have developed a more sophisticated analysis on the changes that were taking place in the system of domination.

Keywords: Revolutionary sindicalism - Law Sáenz Peña - parliamentarism labor movement

Recepción: 6 de diciembre de 2012. Aprobación: 2 de agosto de 2013 